\title{
Evaluation of Real Estate Development Process in Sharia Housing Based on The Application of The Ideal Islamic Housing Concept
}

\author{
Angga Perdana, Purwanita Setijanti and Sarah Cahyadini \\ Department of Architecture, Institut Teknologi Sepuluh Nopember, Surabaya \\ e-mail: anggaperdana.18081@mhs.its.ac.id; psetijanti@arch.its.ac.id; s.cahyadini@arch.its.ac.id.
}

\begin{abstract}
The ideal Islamic housing concept should implement Islamic values holistically in the sharia housing project. The development process of sharia housing looks at housing as not merely a product but also implements shari'ah marketing methods and opens up opportunities for sharia investment in housing finance. Sharia housing with an ideal Islamic housing concept accommodates sharia values in various stages of development, starting from the initial idea formation, feasibility studies, planning and design, funding schemes, employment contracts, marketing selling and buying methods, to estate management. In housing development, the role of investors is important to control the quality of a product that is being developed. A case study strategy was used, with descriptive statistical analysis in evaluating the development process of the Islamic housing concept. Medina Residence 1 was taken as the case study based on their promotion in which they applied the Islamic housing concept in the development process. The evaluation result of the application Islamic housing concept in the development process at Medina Residence 1, shows that the Islamic housing concept has been applied and received a very satisfying response from investors. Therefore, sharia housing developers need to pay attention to it to implement Islamic value in housing development holistically.
\end{abstract}

Keywords-Real Estate Development Process, Ideal Islamic Housing Concept, Sharia Housing.

\section{INTRODUCTION}

$\mathrm{I}_{\mathrm{d}}^{\mathrm{N}}$ $\mathrm{N}$ the field of architecture, one of the most frequently developed sectors is the residential property sector, this is because the main need for people to live is increasingly rising. Therefore, there are many new residential property development projects for the community, both in the form of landed houses, midrise buildings, and highrise buildings. One of the residential property sectors that are currently emerging is the Islamic concept of residential property that applies religious values into housing. The application of these values aims to bring religious values closer together so that the residents get special benefits in their application [1]. The development of real estate with a specific theme becomes a branding that can attract consumers. Many developers have raised the concept of Islamic housing as the branding of developed housing products, but many housings with that concept have not met all the ideal criteria of the concept of Islamic housing both in physical and non-physical aspects, so an evaluation of the application of the concept in shari'a housing is needed [2]. furthermore, with the application of the
Islamic housing concept, sharia capital investment opportunities will arise in the property sector for investors who are interested in investing in the development of the project. Based on the background and formulation that has been explained before, the question of this research is: How is the application of the ideal Islamic housing concept in the development process of shariah housing. The objectives of this study are evaluating the application of the ideal Islamic housing concept in the development process of the shari'a housing project.

\section{THEORY AND METHODS}

The definition of real estate activity itself is an attempt to increase the value of a property to produce a mutual benefit. One of the implementations of real estate is to convert less active or vacant land into buildings so that it produces a profit. The success of real estate development is determined by how the real estate process works. In developing real estate usually goes through several stages of the planning and design process [3].

\section{A. Sharia Housing Development Process}

The theory of real estate planning proposed by Miles is sufficiently detailed in discussing the process and stages of development in eight stages, each of which can be further translated with more specific supporting theories, so that this theory can be developed into a sharia-based housing development theory ' ah who apply Islamic sharia values from the early stages of development to the final stage[3].

The inception of an idea of shariah housing was developed residential real estate with the ideal Islamic housing concept, with the main market share is the people who want to get housing that can actualize Islamic values in it. The initial idea of the development of sharia housing must show the existence of a vision, mission, and goals that lead to the application of Islamic sharia to housing [2].

The refinement of the idea stage is the process of study and excavation of planning and design criteria with themes following the initial idea. In the development of shari'ah housing, this sharpening phase refers to the criteria that must be met to develop a real estate with the ideal Islamic housing concept. After the ideal Islamic housing concept, at the refinement of the idea, there are special programs that support the implementation/realization of Islamic sharia in life in housing [2]. 
The $6^{\text {th }}$ International Seminar on Science and Technology (ISST) 2020

July $25^{\text {th }}$ 2020, Institut Teknologi Sepuluh Nopember, Surabaya, Indonesia

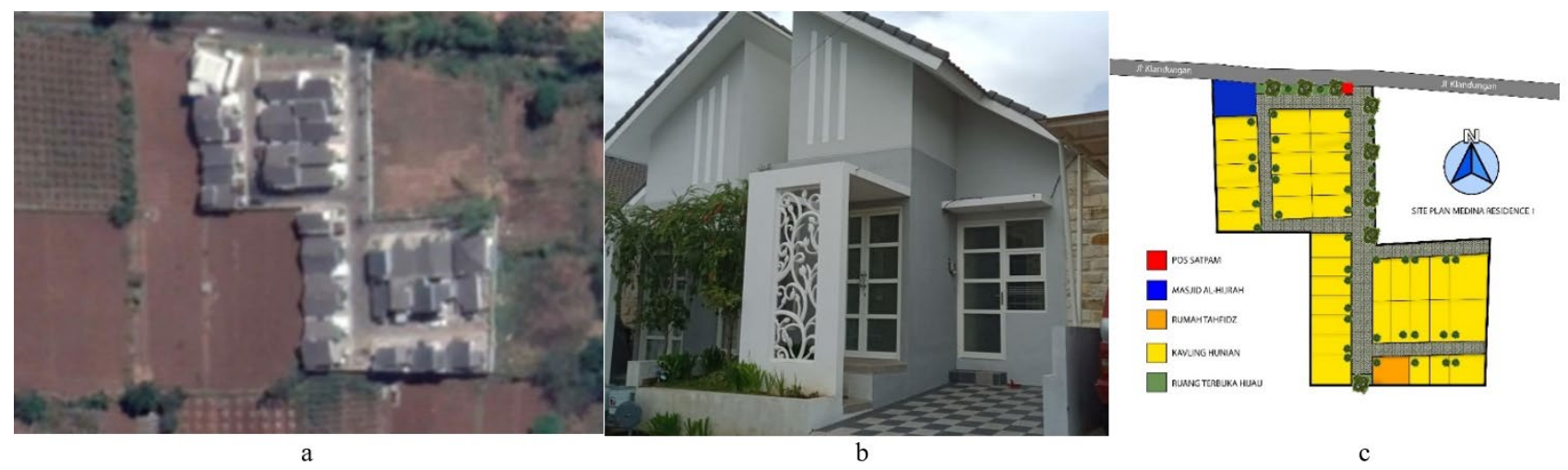

Figure 1. a) Satelite Photo; b) Housing Design; c) Site Plan of Medina Residence 1.

Table 1.

Investor Respons of Real Estate Development Process Evaluation

\begin{tabular}{clccccc}
\hline \hline No & \multicolumn{1}{c}{ Development Stage } & Min & Max & Mean score & Std. Deviation & N \\
\hline 1 & Inception of An Idea & 5 & 6 & 5.5 & 0.707 & 18 \\
2 & Refinement of Idea & 4 & 6 & 5.333 & 0.594 & 18 \\
3 & Feasibility & 4 & 6 & 5.5 & 0.618 & 18 \\
4 & Contract Negotiation & 4 & 6 & 5.444 & 0.616 & 18 \\
5 & Formal Commitment. & 4 & 6 & 5.556 & 0.616 & 18 \\
6 & Construction & 4 & 6 & 5.444 & 0.705 & 18 \\
7 & Completion and Formal Opening & 4 & 6 & 5.667 & 0.485 & 18 \\
8 & Property Management & 5 & 6 & 5.5 & 0.618 & 18 \\
\hline
\end{tabular}

The feasibility study is the final stage of the planning process which will then be continued with the physical design process of a project.At this stage, the architect's role is very dominant. In the development of Sharia housing, the ideal Islamic housing concept is actualized in a real estate project with a physical architecture that is suitable for branding with Islamic housing following the design and planning criteria that were formulated in the previous stage. One of the principles of Islamic housing is not located in disaster-prone areas, water catchment areas, technical irrigation fields, and flood areas so that the land can be declared feasible to be developed [2]. Also, in preparing the feasibility study must consider licensing and applicable regulations such as RUTR information, land use permits, location permits, environmental impact analysis, site plan approval, and developed land does not occur disputes and problems between developers and landowners so that no forced land acquisition occurred [2].

The Contract Negotiation stage in Sharia housing is the stage of formulating the project funding, implementation, and management schemes. In the context of Islamic economics, the funding system (finance), one of which is the Mudharabah system, is often used in sharia-based property development with profit-sharing schemes between stakeholders or capital owners and business operators, in this case, developers. This stage also discussed how the methods and schemes of project implementation and management, so that it will be discussed starting from the method of funding with investors, implementation with construction contractors, and management with management of housing that was developed. In the ideal Islamic housing concept, every negotiation of the sale and purchase of goods and services must bring benefits/benefits to the parties involved, then it is forbidden to use the Ribawi system [2].

The formal agreement is the process of contracting and officially signing of contracts between parties involved in sharia housing development projects. In the Shari'ah housing context, this process is called the Shari'a contract, the process of this agreement is the understanding and willingness of both parties to cooperate to develop real estate and carry out all the processes following the preceding articles. Also, a work contract is made between the developer and the contractor. Following the ideal Islamic housing concept, all agreements must be contained in official, clear, and not contradictory documents of Islamic Sharia [2].

The construction stage is the main process of real estate development. In this stage, a lot of actors were involved, including architect, structural expert, MEP expert, interior expert, acoustic expert, lighting expert, and estimator. While in the operational implementation required a project manager who will oversee and carry out the technical aspects of development. The marketing manager is needed during the implementation phase to get prospective buyers so that buyers can indeed or can immediately buy when the building construction process is completed in the context of housing, then the selected developers and contractors will carry out the physical construction process, in Shari'ah housing one of the most important elements in the area is the construction of worship facilities that are characteristic of Shari'ah housing so that in general developers will build these facilities 
The $6^{\text {th }}$ International Seminar on Science and Technology (ISST) 2020

July $25^{\text {th }} 2020$, Institut Teknologi Sepuluh Nopember, Surabaya, Indonesia

Table 2.

Research Finding

\begin{tabular}{lll}
\hline \hline Development Process & \multicolumn{1}{c}{ Theory and References } & Finding \\
\hline $\begin{array}{l}\text { The inception of An } \\
\text { Idea }\end{array}$ & $\begin{array}{l}\text { There are a vision, mission, and goals that lead to the } \\
\text { application of Islamic sharia in housing [2] }\end{array}$ & $\begin{array}{l}\text { There is an outreach to investors when initiating initial ideas } \\
\text { about the development of sharia housing with the ideal Islamic } \\
\text { housing concept }\end{array}$ \\
\hline
\end{tabular}

Refinement of Idea The existence of special programs that support the implementation/realization of Islamic sharia in life in housing [2].

- There is a forum between developers and investors to discuss sharpening ideas in the form of design, funding, implementation, sales, and management criteria.

- There is a discussion with investors and a team of experts from the development of Islamic residential criteria that will be developed sustainably so that investors can provide feedback on the criteria to be developed

\begin{tabular}{l}
\hline - Neasibility located in disaster-prone areas, water catchment \\
areas, technical irrigation fields, and flood areas [2]. \\
- In the acquisition of land for housing development \\
several things need to be considered, namely: \\
Information on the RUTR; Land Use Permit; Location \\
permission; Permission regarding Amdal; Ratification \\
of the Site Plan. \\
- The developed land does not occur disputes and \\
problems between the developer and the landowner so \\
that no land acquisition is forced [2].
\end{tabular}

- There is a special presentation on the feasibility study of the project to be developed, as well as a discussion on technical matters that will be carried out in housing development.

- There is an explanation of the ideal Islamic housing concept at each stage of development, namely planning, design and implementation.

- There is clarity regarding the land to be developed.

- There is a description of the specifications, clarity, land permits, and land acquisition schemes.

\section{Contract Negotiation Any receivables that bring benefit/profit, then it is usury so it is forbidden to use the Ribawi system [2].}
- There are negotiations regarding the funding agreement and profit-sharing in each investment scheme offered.
- There are official negotiation documents on Mudharabah investments carried out along with the estimated magnitude of risk that can occur during the investment process along with solving the problem in the form of exposure and discussion

\begin{tabular}{ll}
\hline Formal Commitment. & $\begin{array}{l}\text { All agreements are contained in official, clear, and not } \\
\text { incompatible understanding documents of Islamic law } \\
{[2] .}\end{array}$
\end{tabular}
[2].
- The specifications of the building and facilities planned must be following what has been planned and promoted

- There is investor control over the quality of development.

- There are monthly sales reports to investors
There is an official document and has legal force for the profitsharing agreement that is based on the applicable regulations and fatwa related to Mudharabah investment that will be carried out.

- There are periodic project implementation reports to investors so that investors are aware of the progress of the business carried out by the developer.

- There are routine inspections that can be done by representatives of investors to find out the progress made by the developer related to the implementation of housing construction, as well as there is a discussion about the progress being carried out.

\begin{tabular}{ll}
\hline Completion and & - In the handover of houses/housing the quality and \\
Formal Opening & $\begin{array}{l}\text { specifications promised are following those offered at } \\
\text { the contract. } \\
\text { - There is timeliness in the delivery of the house }\end{array}$
\end{tabular}

- There is timeliness in the delivery of the house [2].

Property Management To fulfill the element of trust between the seller and the buyer, then in the sale of Islamic housing, at least the land certificate has been held by the consumer [2].
- Involve investors in the inauguration and opening and delivery of housing to ensure that the business runs as promised.

- There are reports to investors about the units that have been handed over to the user so that investors can monitor the development of the project

There is ongoing reporting on housing management and management to investors so that investors know how the housing management works are following the plan or something that still needs to be improved together with physical development housing. In the ideal Islamic housing concept, construction implementation must pay attention to the suitability of building and facility specifications that have been planned and promoted. Also, each stage of development must be carried out by the investor to control the quality of development results. Then every month there must be a sales report to investors to show the transparency of the business is managed.

Completion and formal opening of real estate projects is the last step of construction, in this stage support utilities are connected, such as electrical, telephone, and other utility lines. So with a careful plan and complete permit management, this activity will not be hampered. Operational workers must be prepared before the project opening process. In the context of Sharia housing in general, it is marked by the handover of residential units to consumers, and at this stage, the investment process is still ongoing until the specified investment period is complete. During the process, the developer is obliged to provide dividends for the results of the project work to investors following the agreed contract. Following the concept of an ideal Islamic residential home handover process must be following the quality and 
The $6^{\text {th }}$ International Seminar on Science and Technology (ISST) 2020

July $25^{\text {th }} 2020$, Institut Teknologi Sepuluh Nopember, Surabaya, Indonesia

specifications promised at the time of the contract. Also, it must pay attention to the timeliness in the delivery of the house [2].

Property management is one of the obligations of a real estate developer, the obligation of developers is not limited to the development of housing units to be purchased by consumers. The development of a real estate includes the development of property land which is divided into private land and public land. Public land is often used for public facilities that support residential areas. The facilities emphasized in the Islamic housing concept are the existence of a place of worship in the form of a small mosque as the main supporting facilities that characterize a residential or real estate concept of an ideal Islamic dwelling. Following the ideal Islamic housing concept, to fulfill the element of trust between seller and buyer, then in the sale of Islamic housing, at least the land certificate has been held by the consumer [2].

\section{B. Research Methods}

In this study discusses the evaluation of the real estate development process based on the application of the ideal Islamic housing concept in housing, therefore the paradigm of this research is the post-positivistic paradigm with the two phases combined strategy research methodology [4], namely in the initial stages of the study a qualitative research methodology is conducted on the application of the ideal Islamic housing concept on the object of research which will be reviewed using descriptive qualitative analysis methods[5]. After being analyzed it will be presented to investors to ask the results of the analysis to be evaluated using interview and questionnaire techniques to find out how far the application of Islamic housing concepts to the results of housing development [6].

The object of this study is the sharia housing Medina Residence 1 Figure 1, this housing was chosen because it generally uses the shari'ah concept as a whole. The application of the sharia concept can be seen from the planning, design, funding, marketing, and estate management stages.

\section{RESULT AND DISCUSSION}

Applying the ideal Islamic housing concept is very important to realize an atmosphere of Islamic housing as a whole, both physically, spiritually, socially, culturally, and economically. Evaluation of the Medina Residence 1 housing development process in applying the ideal Islamic housing concept, can be seen at every stage of its development. Evaluation of the application of the ideal Islamic housing concept in the process of developing an ideal Islamic housing concept can be analyzed based on the following stages.

The inception of an idea to conceptualize the ideal Islamic housing concept in Medina Residence 1 received a mean score of the response of 5,500 so that it was very representative according to investors. In Table 1 row number 1 , the majority of investors tend to choose very strongly agree with the socialization of the ideas of the concept of Medina Residence 1 housing between developers and investors. According to investors, there has been ideal socialization of
Islamic housing concept ideas from developers to investors. The socialization process is through Whatsapp group, by presenting an overview of the initial design related to housing plans, development plans, and floor plans for each type of building unit in Medina Residence 1.

The Refinement of Idea there is a discussion about the design criteria and concepts to be developed. In Medina Residence 1 housing, the mean score of response is 5.333 so that the results are very representative according to investors. In Table 1 row number 2 , the majority of investors tend to strongly agree that there is a discussion about the concept design criteria that will be applied to the Medina Residence 1 housing complex. According to investors, there has been discussion at the development stage between developers and investors, at every stage of development, the developer always informs investors. And there is a discussion about the design criteria that should be used in designing housing at Medina Residence. With the discussion, the resulting design will be more specific and pay attention to the principles of housing in Islamic teachings.

Based on responses from housing investors in the feasibility preparation sub-variable using the ideal Islamic housing concept in planning, designing, and implementing it on Medina Residence 1 housing, the mean score response was 5.500 so that the results were highly representative according to investors. In Table 1 row number 3 , the majority of investors tend to choose very strongly that there is an exposure to a feasibility study and project design and implementation plan for a Medina Residence 1 housing investor. Considering some investors are not in the city of Malang. However, for investors with locations that are quite affordable, sometimes they conduct field visits as well as discuss directly with the developer.

Based on responses from housing investors in the negotiation sub-variable stage, the concept of an ideal Islamic residential and Mudharabah investment sharing system for Medina Residence 1 housing investors received a mean score of the response of 5.444 so that the results were highly representative according to investors. In Table 1 row number 4 , 1 the majority of investors tend to choose strongly agree and very strongly agree that there is a socialization of project financing schemes and Mudharabah profit-sharing systems to housing investors Medina Residence 1. According to investors, there is exposure to the project financing scheme and profit-sharing system from developers to investors. The presentation is done by visiting each investor's house if possible to explain directly. Then explained in detail related to the project profit sharing. However, in Medina Residence 1 because it is still in the early stages of development, several things are delivered in stages, not in full.

Based on responses from housing investors in the Subvariable Stage of agreeing with the investor using the contract following the Mudharabah rules in the Medina Residence 1 housing, the mean score response was 5.556 so that the results were very representative according to the investor. In Table 1 row number 5 , the majority of investors tend to choose very strongly agree that there is a Mudharabah profit-sharing agreement that is following the principles of shari'ah investment to housing investors Medina Residence 1. 
The $6^{\text {th }}$ International Seminar on Science and Technology (ISST) 2020

July $25^{\text {th }} 2020$, Institut Teknologi Sepuluh Nopember, Surabaya, Indonesia

According to investors, many of the investors do not understand related to the principle of shari'a investment, but the developer has given an explanation at the stage of exposure and explained the agreement on the production sharing agreement clearly and following the Shariah.

Based on responses from housing investors on the Implementation Stage sub-variable applying the ideal Islamic housing concept to the physical building, area, marketing, and management of the Medina Residence 1 housing, the mean score response was 5.444 so that the results were highly representative according to investors. In Table 1 row number 6 , the majority of investors tend to choose very strongly that there is a report on the implementation of the construction to housing investors Medina Residence 1. According to investors so far there have been reports of sales submitted to investors. Because in the 2nd week until the 3 rd week has been sold as a whole, the sales report has also ended. For the report on the implementation of development, the percentage that has been built and has not yet existed.

Based on responses from housing investors on the Inauguration Stage sub-variable and the opening and handover of housing carried out following the agreed agreement on housing Medina Residence 1 gets a mean score of the response of 5.667 so that the results are already very representative according to investors. In Table 1 row number 7 , the majority of investors tend to choose very strongly agree that there are reports on project progress and project sales to housing investors Medina Residence 1. According to investors, there are reports on project development, both when opening new land, and when the handover of units to consumers should be representative of investors included so that investors know the development process in greater depth. When opening a new project the developer always informs investors to take part in investing in the latest projects. Housing opening activities are also carried out by involving representatives of investors or investors who can reach locations to visit the field.

Based on responses from housing investors on the Management and housing management sub-variable accommodating the needs according to the ideal Islamic housing concept in Medina Residence 1, the mean score of response was 5.500 so that the results were very representative according to investors. In Table 1 row number 8 , the majority of investors tend to choose very strongly agree that there are project managerial reports, project management, and clear profit sharing to housing investors Medina Residence 1. According to investors, there are no detailed project managerial and project management reports. However, the distribution of results of a business is always informed about the schedule of return on capital and schedule of results. Reports on each project progress should be informed to investors openly so that investors know what the process of housing development is funded in more detail so that if something happens, it can provide input to developers to improve the quality of sales, implementation, and managerial and project portfolios.

\section{A. Research Finding}

Based on the results of an evaluation analysis of investor interviews and a descriptive statistical analysis of questionnaires that have been carried out on the development process of sharia housing based on the application of the ideal Islamic housing concept, all indicators are found that indicate that housing is meet the ideal Islamic housing concept. These findings support the research on the application of the principles of Islamic housing to Muslim housing in the Bukit Az-Zikra [2]. Where the Islamic housing concept of housing must apply the principles that contain Islamic sharia values in it in every aspect and stage of its development in Table 2.

\section{CONCLUSION}

Based on the results of evaluations and in-depth analysis qualitatively and quantitatively about the application of the ideal Islamic housing concept and investment satisfaction. It shows that the Medina Residence 1 case study has applied the ideal Islamic housing concept. This is based on the evaluation results of the application of the ideal Islamic housing concept in the Medina Residence 1 case study, received a response with a mean score of 5.493 on a scale of 6 . Or it can be said that $91.55 \%$ of the ideal Islamic housing concept has been applied to the housing development process very satisfactorily. The difference between common housing and sharia housing can be seen in the application of Islamic law and guidance for developing housing projects as a physical and non-physical object. As a physical object, sharia housing must interpret Islamic character in the building design. As non-physically object Islamic housing is an interpretation of Islamic living guidance. The principle of Islamic housing is the principle of trustworthiness and transparency of the development process. Furthermore, this principle can make all stakeholders in this project have a mutual benefit from the development process.

\section{REFERENCES}

[5] Poerwandari, E.K., Pendekatan Kualitatif. Cetakan ketiga. 2009, Depok: Lembaga Pengembangan Sarana Pengukuran dan Pendidikan Psikologi Fakultas Psikologi UI.

[6] Sugiyono, Statistika Untuk Penelitian. Dra. Endang Mulyatiningsih,M.Pd ed. 2007, Bandung: CV. Alfabeta.

Hwaish, A.-M., Concept of Islamic House; A Case Study for Early Muslims Traditional House. 2018.

Amalia, Z., Pranggono, B, Kajian Penerapan Prinsip-prinsip Seminar Penelitian Sivitas Akademika Unisba, 2017. 3(2).

Miles, M.E Urban. .L.I., Real estate development: principles and process. 2013, Washington, D.C.: Urban Land Institute.

Groat, L.N.Wang., D., Architectural Research Methods. 2013: Groat, L.N.Wang., D., Architectural Research Methods. 2013: [5]

(6)

